to attain this coveted honour in competition with those whose lives are devoted to academic science. Even after he had had warnings of angina pectoris he made a long trip to Canada and visited many places in the wilds which could only be reached by aeroplane.

Usher was a very reserved man-so much so that he gave the impression of resenting any approach to intimacy. There was a strong streak of Puritanism in his character, and his unwavering adherence to what he considered right sometimes revealed a lack of savoir faire which alienated his colleagues. Thus, he refused to accept the honorary degree of LL.D. of Aherdeen University because it had previously been conferred on one whom he deemed unworthy of the honour. Yet to those who succeeded in penetrating his armour and gaining his confidence he was a staunch friend and a delightful companion. He was a keen fisherman and a good ornithologist. He was passionately fond of music, and found much enjoyment in playing the 'cello in a string quartette which met weekly at his house.

\title{
LIEUT.-COLONEL H. HERBERT
}

IT is with great regret that we announce the death at Worthing, on March 19, 1942, of Lieut.-Colonel Herbert Herbert, I.M.S. (ret.). $\mathrm{He}$ was aged 77 years and had been living in retirement of late. As an ophthalmic surgeon Herbert achieved very much more than a purely British reputation. His work at Bombay, both in the clinical and pathological field, was of outstanding value and was conducted in a truly scientific spirit. His description of the "pits," since known as Herbert's pits in the cornea of trachomatous patients was the first of its kind. In this, as in much else he was a pioneer; and it should be emphasized that he did all the microscopical work on his cases in his spare time. The other subject on which Herbert was brought into prominence was of course glaucoma. In varying parts of the world surgeons were engaged on devising some operation for types of glaucoma, which it was agreed, did not always do well on the classical iridectomy of von Graefe. Thus Lagrange, in France, Freeland Fergus, in Glasgow, Holth, in Scandinavia, Herbert, in Bombay and Elliot, in Madras were all at work on this subject in the early years of the present century. It was a great pity that Herbert's description of his first, or wedge-shaped, sclerotomy was so involved as to be difficult to understand from the verbal account; and we do not think that it ever found much support in England. But his later, or trap-door, sclerotomy has been extensively used and has a permanent place in our operative procedures in selected cases. Besides his work on glaucoma he wrote a good deal on cataract. 
Herbert joined the Ophthalmological Society in 1897 and served a term as vice-president. He qualified from Leeds in 1886 and took the F.R.C.S. (Eng.) in 1891. At Bombay he was ophthalmic surgeon to the Sir C. J. Ophthalmic Hospital from 1895 to 1907. $\mathrm{He}$ was also a Fellow of Bombay University.

On retirement Herbert settled at Nottingham and was surgeon, and later consulting surgeon, to the Nottingham and Midland Eye Infirmary. About twenty years ago he moved to Worthing where he was ophthalmic surgeon to the Worthing Hospital and Pathologist to the Sussex Eye Hospital. He contributed many papers to the Transactions of the Ophthalmological Society, to the Ophthalmic Review and to our columns.

Herbert was a quiet, friendly man, tenacious of his own opinions but never ultra-dogmatic or self-seeking. His work was done in the scientific interests of his subject; he fought well for his beliefs but was always a courteous and kindly opponent.

\section{NOTES}

Death

WE regret to record the death of George William Kendall, of Stoke Newington, and of 11, Devonshire Place, on February 16, 1942. His education was received in Ireland where he qualified M.B., B.Ch. in 1893 and where he proceeded M.D. in 1895 .

He held honorary appointments at Hitchin and St. Albans and was a regular member of the Oxford Ophthalmological Congress and the Ophthalmic Section of the Royal Society of Medicine. Early in his career he had worked at Moorfields as Chief Clinical Assistant and during the 1914-18 War he was an ophthalmic specialist to the Army with the rank of Captain, R.A.M.C. Later he served as ophthalmic surgeon to the Ministry of Pensions. Kendall was interested in professional organization and was a member of the City Division of the British Medical Association, of which he had been President in 1929. He contributed some papers to the Proceedings of the Section of Ophthalmology of the Royal Society of Medicine. As oculist to the Hertfordshire County Council Schools and to the London Teachers Association he knew well the problems connected with vision, both of scholars and teachers.

Honour Group Captain P. C. Livingston has been twenty years' standing. 